Article

\title{
Foulant Identification and Performance Evaluation of Antiscalants in Increasing the Recovery of a Reverse Osmosis System Treating Anaerobic Groundwater
}

\author{
Muhammad Nasir Mangal 1,2,*(D), Sergio G. Salinas-Rodriguez ${ }^{1}$ (D) Jos Dusseldorp ${ }^{3}$, Bastiaan Blankert ${ }^{3,4}$ (D), $^{\text {, }}$ \\ Victor A. Yangali-Quintanilla ${ }^{5}$, Antoine J. B. Kemperman ${ }^{2} \mathbb{D}_{\text {, Jan C. Schippers }}{ }^{1}$, Walter G. J. van der Meer ${ }^{2,3}$ \\ and Maria D. Kennedy ${ }^{1,6}$
}

check for

updates

Citation: Mangal, M.N.;

Salinas-Rodriguez, S.G.; Dusseldorp,

J.; Blankert, B.; Yangali-Quintanilla,

V.A.; Kemperman, A.J.B.; Schippers,

J.C.; van der Meer, W.G.J.; Kennedy,

M.D. Foulant Identification and

Performance Evaluation of

Antiscalants in Increasing the

Recovery of a Reverse Osmosis

System Treating Anaerobic

Groundwater. Membranes 2022, 12,

290. https://doi.org/10.3390/

membranes 12030290

Academic Editor: Marek Gryta

Received: 2 February 2022

Accepted: 26 February 2022

Published: 2 March 2022

Publisher's Note: MDPI stays neutral with regard to jurisdictional claims in published maps and institutional affiliations.

Copyright: (C) 2022 by the authors. Licensee MDPI, Basel, Switzerland. This article is an open access article distributed under the terms and conditions of the Creative Commons Attribution (CC BY) license (https:// creativecommons.org/licenses/by/ $4.0 /)$.
1 IHE Delft Institute for Water Education, Water Supply, Sanitation and Environmental Engineering Department, Westvest 7, 2611 AX Delft, The Netherlands; s.salinas@un-ihe.org (S.G.S.-R.); jancschippers@gmail.com (J.C.S.); m.kennedy@un-ihe.org (M.D.K.)

2 Faculty of Science and Technology, University of Twente, 7500 AE Enschede, The Netherlands; a.j.b.kemperman@utwente.nl (A.J.B.K.); w.g.j.vandermeer@utwente.nl (W.G.J.v.d.M.)

3 Oasen Drinkwater, Nieuwe Gouwe O.Z. 3, 2801 SB Gouda, The Netherlands; jos.dusseldorp@oasen.nl (J.D.); bastiaan.blankert@kaust.edu.sa (B.B.)

4 Water Desalination and Reuse Center (WDRC), Biological and Environmental Science and Engineering Division (BESE), King Abdullah University of Science and Technology (KAUST),

Thuwal 23955-6900, Saudi Arabia

5 Grundfos Holding A/S, Water Solutions, Poul Due Jensens Vej 7, 8850 Bjerringbro, Denmark; vyangali@grundfos.com

6 Faculty of Civil Engineering, Delft University of Technology, Stevinweg 1, 2628 CN Delft, The Netherlands

* Correspondence: m.mangal@un-ihe.org

\begin{abstract}
The objectives of this study are to assess the performance of antiscalants in increasing the recovery $(\geq 85 \%)$ of a reverse osmosis (RO) plant treating anaerobic groundwater (GW) in Kamerik (the Netherlands), and to identify scalants/foulant that may limit RO recovery. Five different commercially available antiscalants were compared on the basis of their manufacturer-recommended dose. Their ability to increase the recovery from $80 \%$ to a target of $85 \%$ was evaluated in pilot-scale measurements with anaerobic GW and in once-through lab-scale RO tests with synthetic (artificial) feedwater. A membrane autopsy was performed on the tail element(s) with decreased permeability. X-ray photoelectron spectroscopy (XPS) analysis indicated that calcium phosphate was the primary scalant causing permeability decline at $85 \%$ recovery and limiting $\mathrm{RO}$ recovery. The addition of antiscalant had no positive effect on RO operation and scaling prevention, since at $85 \%$ recovery, permeability of the last stage decreased with all five antiscalants, while no decrease in permeability was observed without the addition of antiscalant at $80 \%$ recovery. In addition, in lab-scale RO tests executed with synthetic feed water containing identical calcium and phosphate concentrations as the anaerobic GW, calcium phosphate scaling occurred both with and without antiscalant at $85 \%$ recovery, while at $80 \%$ recovery without antiscalant, calcium phosphate did not precipitate in the RO element. In brief, calcium phosphate appeared to be the main scalant limiting RO recovery, and antiscalants were unable to prevent calcium phosphate scaling or to achieve a recovery of $85 \%$ or higher.
\end{abstract}

Keywords: calcium phosphate scaling; anaerobic groundwater; antiscalants; reverse osmosis; fouling

\section{Introduction}

One of the main developments in water treatment over the last few decades has been the advent of reverse osmosis (RO) technology. Due to the continuous development of $\mathrm{RO}$, the decreasing prices of membrane technology, and its small footprint and excellent removal of contaminants (e.g., organic micro pollutants (OMPs), viruses, etc.) [1], the use of $\mathrm{RO}$ has been increasingly applied in the treatment of groundwater $(\mathrm{GW})$ and surface water, 
which are the main sources for producing drinking water in many countries worldwide. For instance, in the Netherlands, over $60 \%$ of the produced drinking water by Dutch water supply companies is obtained from the treatment of GW [2,3], and several of these companies have adopted (or are investigating) the use of RO technology to produce highquality drinking water.

Though RO technology has gained popularity in the water treatment sector and is widely accepted, it still faces some challenges, such as membrane fouling, that need to be addressed. Membrane fouling has an adverse effect on the operation of RO, including, but not limited to, the permeability loss of the membranes, increased pressure needs leading to higher operating expenses, an increase in salt passage of the RO permeate, and a shorter membrane lifetime as a result of frequent cleanings [4]. In RO processes, various types of fouling can be encountered, such as particulate fouling, organic fouling, biofouling, and scaling [5-8]. Particulate fouling is caused by the deposition of colloidal and suspended material (silt, clay, iron oxides, etc.) present in the RO feed onto the membrane surface [9-11]. Organic fouling is usually encountered when the RO feed contains high concentrations of natural organic matter (e.g., humic substances (HS)) [12,13]. Biofouling is the attachment and growth of microorganisms on the feed spacer and membrane surface in $\mathrm{RO}$ processes [14-16]. In GW applications, especially the RO treatment of anaerobic GW, biofouling is not encountered [1,17]. Lastly, scaling refers to the crystallization and precipitation of sparingly soluble salts on the membrane surface that can occur when the concentration of the salts on the membrane surface exceeds their solubility limits [4].

Scaling is a major challenge in brackish water RO applications (BWRO), and is typically the key barrier in operating RO systems at high recovery rates [18]. Maximizing recovery in BWRO is highly desirable to minimize the total electrical consumption per unit volume of permeate, maximize water production, decrease the amount of concentrate, and lower the use of pretreatment chemicals and their related costs [19]. At high recoveries, the concentration of the dissolved inorganic compounds in the concentrate can increase considerably, as much as four to ten times for recoveries in the $75-90 \%$ range, and, consequently, exceed the solubility limits for several types of salts, which can lead to membrane scaling [20].

Depending on the inorganic ion composition of the RO feed, various compounds such as calcium carbonate, calcium phosphate, silica, etc. can precipitate in RO installations. Calcium carbonate is one of the most commonly encountered scales on $\mathrm{RO}$ membranes. The formation and degree of calcium carbonate scaling depend on the calcium and bicarbonate concentrations [20,21], as well as on $\mathrm{pH}$ and temperature [22]. When the RO feed contains a high concentration of calcium and orthophosphate ions, calcium phosphate scale can form on the membrane surface $[23,24]$. Calcium phosphate can be mainly encountered in water reuse applications, as well as in the RO treatment of GW. Calcium phosphate can exist in an amorphous form and in various crystalline forms [25]. In $\mathrm{RO}$ applications, the amorphous phase of calcium phosphate is reported to be responsible for flux decline $[23,26]$. Silica degrades membrane performance by precipitating as colloidal silica or as metal silicates with ions such as calcium, magnesium, aluminium, etc. [20,27,28]. In GWRO applications, aluminium silicates (e.g., clay in colloidal form) are one of the most commonly encountered compounds which could be present in the RO feedwater and can also cause permeability decline in the first stage [29].

Adding antiscalant to the RO feed is one of the most effective and widely used methods for preventing scaling and achieving high recoveries in $\mathrm{RO}$ applications. [30-32]. One factor that makes antiscalant addition appealing is the low dose required to overcome scaling [20]. Antiscalants disrupt the crystallization process; more specifically, they hinder the nucleation phase and/or retard the growth phase of crystallization [20,22,33], allowing for higher recovery in $\mathrm{RO}$ applications [34]. There are a variety of commercial antiscalants available that are designed to combat specific types of scale, and the most common ones used in RO applications are phosphonates, polycarboxylates, and biobased antiscalants [20,35]. The selection of antiscalants in $\mathrm{RO}$ applications depends on the feed water composition. 
The antiscalant dose is generally recommended by the antiscalant suppliers, which they calculate using their projection programs. The projection programs of the antiscalant suppliers also predict the maximum achievable recovery and identify the scalants that may limit $\mathrm{RO}$ recovery.

This study was performed in the context of the realization of a future RO plant by a Dutch water supply company (Oasen Drinkwater) in treating anaerobic groundwater for drinking water production. One of the main differences between anaerobic groundwater and aerobic groundwater is the presence of high concentrations of iron in its soluble (ferrous) form due to the absence of oxygen. On the other hand, a high concentration of iron in aerobic groundwater is not expected, since in the presence of oxygen, the formed iron (III) oxide particles (from the oxidation of ferrous to ferric) are retained in the soil pores.

Due to the anticipated increase in salinity and higher standards in the removal of OMPs, the water company aims to replace the existing conventional plant (spray aeration on the surface of rapid sand filters, tower aeration, pellet softening, rapid sand filtration, and granular activated carbon filtration) with $\mathrm{RO}$. The abstraction of anaerobic groundwater and the discharge of concentrate are limited by strict regulations. It is preferable that the water loss, i.e., the concentrate waste stream, in the new $\mathrm{RO}$ is less (or at least equal) to that in the current conventional treatment plant. The current conventional treatment plant has a water loss of about $15 \%$. It is therefore desirable, in this situation, to operate the RO plant at $85 \%$ recovery (or higher), which corresponds to the water loss of the current conventional treatment plant. Increasing $\mathrm{RO}$ recovery will result in lower groundwater abstraction and discharge of concentrate water for a given permeate water production, and thus less water loss (waste). Furthermore, increasing recovery will reduce the specific energy consumption and costs associated with the disposal of concentrate water.

The objectives of this work are:

(a) To identify the foulant/scalants that would precipitate in the $\mathrm{RO}$ unit at $85 \%$ recovery.

(b) To examine the role of antiscalants in increasing the $\mathrm{RO}$ recovery to at least $85 \%$.

In this study, an RO pilot unit was operated with and without antiscalant at $80-85 \%$ recoveries. Membrane autopsy was carried out to identify the scalants/foulant. To explore the effectiveness of the antiscalants, we combined results from the RO pilot, operating with anaerobic GW, and a once-though lab-scale RO system operating with synthetic feedwater.

\section{Materials and Methods}

\subsection{Feedwater (Anaerobic GW) Composition}

The RO feed was anaerobic GW which was obtained from several wells of a (conventional) water treatment plant in Kamerik, the Netherlands. Table 1 shows the composition of the feedwater, which contains high concentrations of ferrous iron. It should be noted that ferrous iron by itself will not cause membrane fouling because it is very soluble. However, if oxygen enters the feedwater, ferrous will oxidize to iron (III), or ferric, and form particle deposits on the membrane surface and spacers, resulting in a decrease in permeability and a rise in pressure drop. Therefore, maintaining the anaerobic status of the feedwater is essential.

The water analysis was carried out by a commercial lab (Vitens Laboratorium, the Netherlands). The major fraction (approximately 62\%) of the dissolved organic carbon (DOC) in the GW was humic substances (HS) of the fulvic acid (FA) type, which was identified with liquid chromatography-organic carbon detection (LC-OCD) (DOC-Labor, Germany).

The RO feedwater data (Table 1) was entered into the projection programs of seven different antiscalant manufacturers (names are not included in this paper) to identify the suppliers' recommended maximum achievable recovery and the scaling compound(s) which may limit RO recovery. The projection programs were also used to assess the scaling potential of the $\mathrm{RO}$ concentrates at various recoveries (with and without antiscalant addition). 
Table 1. Feedwater (anaerobic GW) composition.

\begin{tabular}{lclc}
\hline Cations & $\begin{array}{c}\text { Concentration } \\
(\mathbf{m g} / \mathbf{L})\end{array}$ & Anions & $\begin{array}{c}\text { Concentration } \\
(\mathbf{m g} / \mathbf{L})\end{array}$ \\
\hline Calcium & 115.2 & Sulphate & 43.4 \\
Magnesium & 17.4 & Chloride & 113.6 \\
Sodium & 55.2 & Fluoride & 0.1 \\
Potassium & 5.6 & Bicarbonate & 391.8 \\
Barium & 0.1 & Carbonate & - \\
Strontium & 0.5 & Nitrate & 0.2 \\
Iron $(\mathrm{II})$ & 8.5 & Silica & 16.7 \\
Ammonium & 3.7 & Orthophosphate & 2.1 \\
\hline Other properties of the RO feed: & & & \\
\hline pH & 7.0 & TDS $(\mathrm{mg} / \mathrm{L})$ & $750-800$ \\
Temperature $\left({ }^{\circ} \mathrm{C}\right)$ & 12 & DOC (HS) $(\mathrm{mg} / \mathrm{L})$ & $8.6(5.3)$ \\
Turbidity $(\mathrm{NTU})$ & $<0.1$ & & \\
\hline
\end{tabular}

Tested Antiscalants to Increase RO Recovery to at Least 85\%

Based on the RO feed analysis (Table 1), various antiscalants were recommended by the antiscalant manufacturers with which the RO recovery could be increased to $85 \%$. Table 2 lists the arbitrary names of the tested antiscalants, along with some basic information provided by the antiscalant suppliers.

Table 2. Tested antiscalants as recommended by suppliers for increasing RO recovery to at least $85 \%$.

\begin{tabular}{|c|c|c|c|}
\hline \multirow{2}{*}{ Antiscalants $\Delta$} & \multirow{2}{*}{ Chemical Nature } & \multicolumn{2}{|c|}{ Target Scalants } \\
\hline & & Primary Scalants Targeted & Additional Scalants Targeted \\
\hline AS-1 & Blend of phosphonates and carboxylic acids & Calcium phosphate/carbonate & Silica, iron/clay fouling, etc. \\
\hline AS-2 & Proprietary acrylic polymer with chelate agent & Silica, calcium phosphate & Calcium carbonate, etc. \\
\hline AS-3 & Information not available & Calcium phosphate/carbonate & Silica, clay, metal oxides, etc. \\
\hline AS-4 & A modified polycarboxylate & Calcium phosphate/carbonate & Silica, etc. \\
\hline AS-5 & Sulfonated polycarboxylate & Calcium phosphate & Silica, calcium carbonate, etc. \\
\hline
\end{tabular}

$\Delta$ The antiscalants' real names are replaced with arbitrary names.

\subsection{RO Pilot}

Figure 1 depicts a schematic representation of the RO pilot plant. The RO installation had three stages where the pressure vessel configuration for each stage could be varied. Each pressure vessel contained three hydranautics membrane elements (ESPA2-LD-4040). The anaerobic GW (feedwater) was passed through a cartridge filter $(10 \mu \mathrm{m})$ and then fed to the RO unit. The RO installation was operated at constant permeate water production. To assess the occurrence of scaling, the average normalized (temperature corrected) permeability $\left(\mathrm{K}_{\mathrm{w}}\right.$, Equation (S1)) of the last stage was monitored.

In the first set of experiments, the RO pilot was operated without antiscalant, as described in Table 3, to realize which compounds will precipitate in the RO unit in the absence of antiscalant. After observing a permeability drop (>20\%) in the last stage, the tail membrane element was taken for autopsy. In the second set of experiments (as shown in Table 3), the $\mathrm{RO}$ unit was operated at $85 \%$ recovery with various antiscalants. These experiments were conducted to recognize if a recovery of $85 \%$ (or higher) could be achieved with the use of antiscalants for the RO unit in Kamerik, since according to some antiscalant suppliers, $85 \%$ recovery was an achievable recovery with their antiscalants. The average flux of the last stage in all experiments was in the $10-20 \mathrm{~L} / \mathrm{h} / \mathrm{m}^{2} / \mathrm{bar}$ range. 


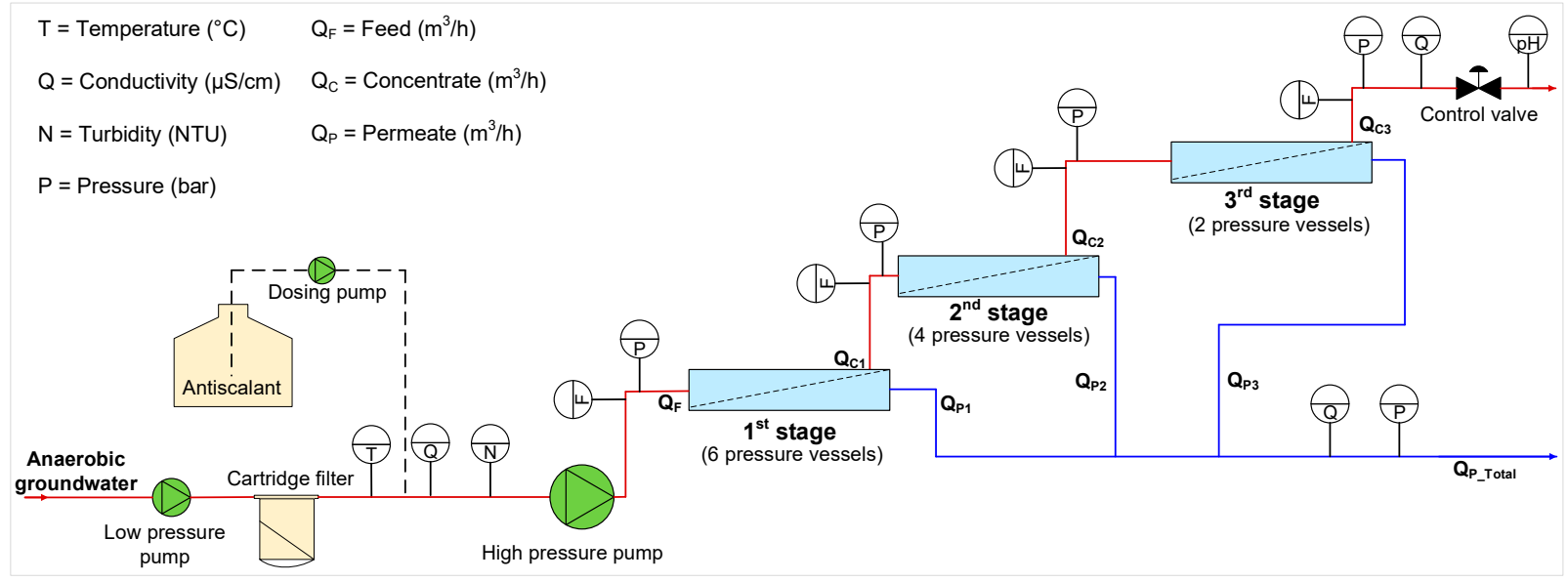

Figure 1. Schematic representation of the RO pilot installation in Kamerik [36].

Table 3. RO operation without antiscalant (to identify scalants that cause permeability decline), and with antiscalants (to increase $\mathrm{RO}$ recovery to $85 \%$ ).

\begin{tabular}{|c|c|c|c|c|c|}
\hline Run & $\begin{array}{l}\text { Pressure Vessel } \\
\text { Configuration }\end{array}$ & $\begin{array}{l}\text { Recovery } \\
(\%)\end{array}$ & Antiscalant & $\begin{array}{c}\text { Antiscalant } \\
\text { Dose }^{\bullet}(\mathrm{mg} / \mathrm{L})\end{array}$ & $\begin{array}{l}\text { Run Period } \\
\text { (Days) }\end{array}$ \\
\hline \multirow{2}{*}{$\mathrm{A}$} & \multirow{2}{*}{ 3-2-1 (6 elements) } & 80 & - & 0 & 10 \\
\hline & & 85 & - & 0 & 32 \\
\hline \multirow{6}{*}{ B } & \multirow{6}{*}{ 6-2-1 (3 elements) } & \multirow{6}{*}{85} & - & 0 & 5 \\
\hline & & & AS-1 & 2.5 & 3 \\
\hline & & & AS-2 & 2.5 & 5 \\
\hline & & & AS-3 & 2.5 & 4 \\
\hline & & & AS-4 & 5.0 & 5 \\
\hline & & & AS-5 & 5.0 & 4 \\
\hline
\end{tabular}

- Tested antiscalant doses were the suppliers' recommended doses.

\subsection{Foulant Characterization}

After operating the $\mathrm{RO}$ unit without antiscalant, all three stages were flushed with $\mathrm{RO}$ permeate. As the membranes were in contact with anaerobic concentrate containing high concentrations of ferrous, flushing with RO permeate was necessary to avoid iron oxidation (and precipitation) while taking out the membranes for autopsy. Membrane autopsy was performed on the tail element of the third stage and first stage. It is worth mentioning that the membrane elements in the third stage were brand new, whereas the membrane elements in the first stage had been in use for over 5 years.

To identify the foulant/scalant which was responsible for the permeability decline of the $\mathrm{RO}$, various techniques were employed, such as scanning electron microscopy with energy dispersive X-ray (SEM-EDX) spectroscopy (JEOL, JSM-6010LA), X-ray powder diffraction (XRD) (Bruker D8 Advance), fluorescence excitation-emission matrix (FEEM) spectrophotometry (FluoroMax-3), and X-ray photoelectron spectroscopy (XPS) (Quantera SXM-Scanning XPS microprobe).

SEM-EDX was used to visualize the foulant and to identify the mass percentages of the elements present in the foulant. To investigate whether the foulant disappears in acidic or basic solutions (or both), membrane coupons of the fouled $\mathrm{RO}$ with a total area of approximately $1000 \mathrm{~cm}^{2}$ were stirred for about $24 \mathrm{~h}$ at $35{ }^{\circ} \mathrm{C}$ in beakers containing either $0.05 \mathrm{M} \mathrm{HCl}$ or $0.05 \mathrm{M} \mathrm{NaOH}$. Afterwards, the membrane coupons were flushed with demineralized water, dried, and then analyzed with SEM-EDX. In the case where foulant was not observed on the membrane coupons (after cleaning) in SEM-EDX analysis, the 
cleaning solutions then were filtered through $0.45 \mu \mathrm{m}$ (cellulose acetate) filters. Afterwards, the $0.45 \mu \mathrm{m}$ filters were flushed with demineralized water, dried, and analyzed with SEMEDX to find out if the foulant dissolved in the cleaning solutions or was just physically detached from the membrane.

XRD analysis was performed on the fouled $\mathrm{RO}$ membrane to examine if the foulant was crystalline, and, if so, which scales were present on the fouled membrane. FEEM analysis was used to examine the cleaning solutions $(0.05 \mathrm{M} \mathrm{HCl}$ and $0.05 \mathrm{M} \mathrm{NaOH})$ to identify the presence of HS on the fouled RO membrane. XPS was used to obtain the binding energies of the foulant present on the membrane surface and to identify the foulant.

\subsection{Lab-Scale RO Unit}

Calcium phosphate was expected to be one of the scalants limiting RO recovery in Kamerik (explained later in the Section 3). Due to the complexity of the water composition of the anaerobic groundwater, i.e., presence of iron and HS, it was necessary to execute once-through lab-scale RO experiments (Figure 2) with synthetic solutions (in the absence of iron and HS) to assess the ability of antiscalants in hindering calcium phosphate scaling. As presented in Table 4, the lab-scale RO experiments were performed with the synthetic concentrate solutions of 80 and $85 \%$ recovery in the absence and presence of antiscalants. The synthetic $\mathrm{RO}$ concentrate solutions had similar $\mathrm{pH}$, calcium, and phosphate concentrations to the real $\mathrm{RO}$ concentrates in Kamerik.
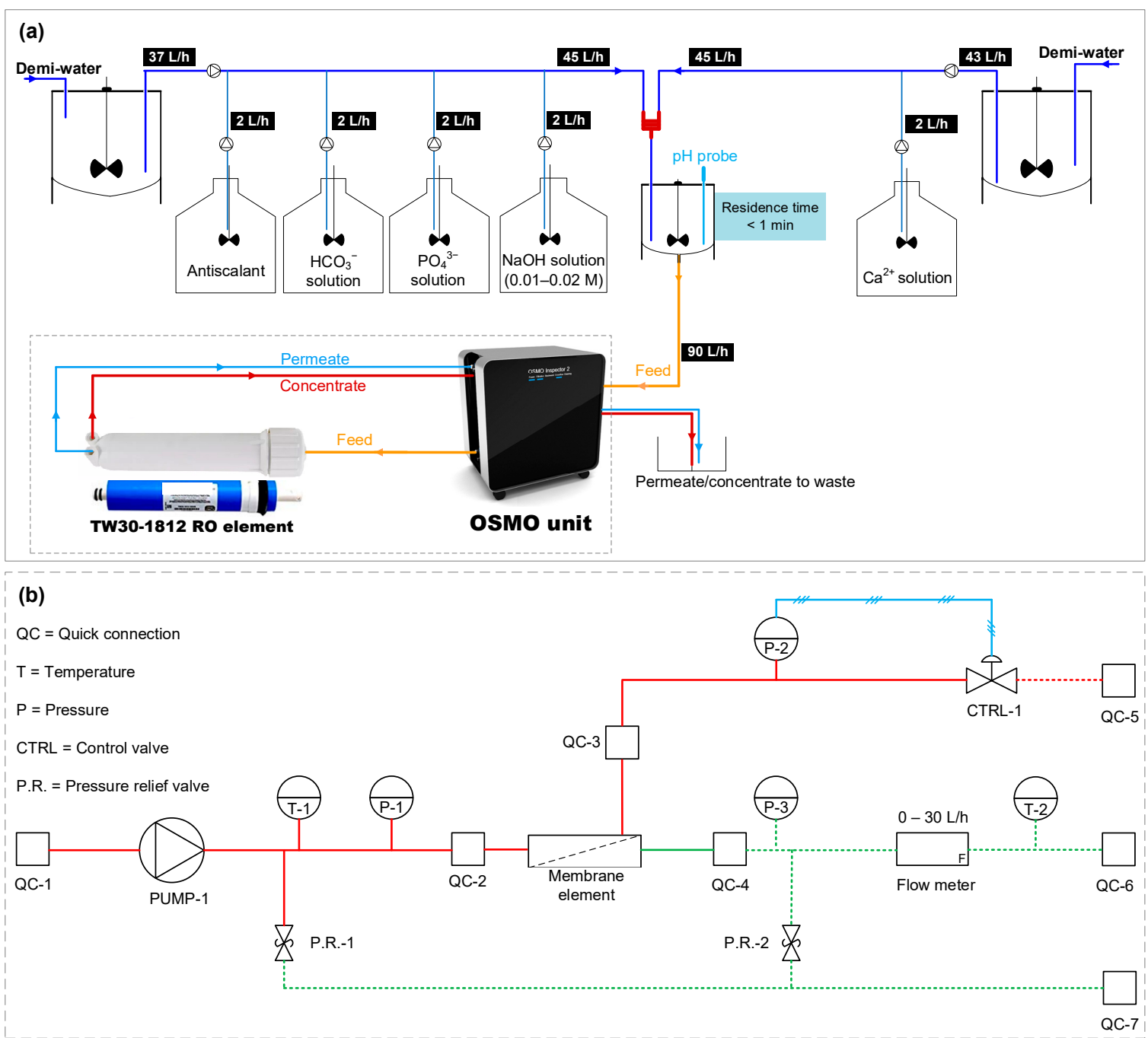

Figure 2. (a) Once-through lab-scale RO setup for testing the performance of antiscalants. (b) Piping and instrumentation diagram of the OSMO unit with the RO element [26]. 
Table 4. Once-through lab-scale RO tests with the synthetic RO concentrates of 80 and $85 \%$ recovery in the absence and presence of antiscalants.

\begin{tabular}{|c|c|c|c|c|c|c|}
\hline Feed Solution & Antiscalant & $\begin{array}{c}\text { Antiscalant Dose } \\
(\mathrm{mg} / \mathrm{L})\end{array}$ & $\begin{array}{c}\mathrm{Ca}^{2+} \\
(\mathrm{mg} / \mathrm{L})\end{array}$ & $\begin{array}{l}\mathrm{PO}_{4}{ }^{3-} \\
(\mathrm{mg} / \mathrm{L})\end{array}$ & $\begin{array}{c}\mathrm{HCO}_{3}^{-} \\
(\mathrm{mg} / \mathrm{L})\end{array}$ & $\begin{array}{l}\mathrm{pH} \\
(-)\end{array}$ \\
\hline $\begin{array}{c}\text { Synthetic concentrate of } \\
80 \% \text { recovery }\end{array}$ & - & 0 & 575 & 10.5 & 200 & 7.4 \\
\hline \multirow{6}{*}{$\begin{array}{c}\text { Synthetic concentrate of } \\
85 \% \text { recovery }\end{array}$} & - & 0 & 767 & 14 & 200 & 7.6 \\
\hline & AS-1 & \multirow{5}{*}{33.3} & \multirow{5}{*}{767} & \multirow{5}{*}{14} & \multirow{5}{*}{200} & \multirow{5}{*}{7.6} \\
\hline & AS-2 & & & & & \\
\hline & AS-3 & & & & & \\
\hline & AS-4 & & & & & \\
\hline & AS-5 & & & & & \\
\hline
\end{tabular}

- The antiscalant dose is the concentration of antiscalant in the synthetic RO concentrate.

The synthetic concentrate solutions were prepared by dosing $\mathrm{Ca}^{2+}, \mathrm{HCO}_{3}{ }^{-}, \mathrm{PO}_{4}{ }^{3-}$, and $\mathrm{NaOH}$ from their stock solutions to the demineralized water (demi-water). The synthetic concentrate solutions were stirred in a reactor at $200 \mathrm{rpm}$ for less than $1 \mathrm{~min}$ before being fed to the membrane element. The volume of the synthetic concentrate in the reactor was kept constant at $1 \mathrm{~L}$, and the flows entering and exiting the reactor were both kept constant at $90 \mathrm{~L} / \mathrm{h}$, allowing for a residence time of less than $1 \mathrm{~min}$.

An OSMO inspector unit (Convergence Industry B.V., the Netherlands) was used to feed the synthetic concentrate solution to a TW30-1812-50 RO element (OsmoPure Water Systems). An Atrato ultrasonic flow meter was installed in the OSMO unit, which could measure permeate flow rates ranging from $0.12 \mathrm{~L} / \mathrm{h}$ to $30 \mathrm{~L} / \mathrm{h}$. A new TW30-1812-50 RO element was used in each experiment.

In all tests, the initial recovery of the RO element was $5-6 \%$ and the permeate flux was $13-15 \mathrm{~L} / \mathrm{m}^{2} / \mathrm{h}$. The cross-flow velocity was between 10 and $12 \mathrm{~cm} / \mathrm{s}$. All lab-scale RO tests were executed at room temperature $\left(20-22^{\circ} \mathrm{C}\right)$.

\section{Results and Discussion}

\subsection{Maximum Achievable Recovery Based on Antiscalant Suppliers' Projection Programs}

In this section, the maximum achievable recovery and the scalants that limit RO recovery according to the projection programs of the antiscalant suppliers are discussed. In addition, the scaling potential (of some commonly encountered scalants) at 80 and $85 \%$ recovery with and without antiscalant (according to the projection software) is presented.

Figure 3a shows the maximum achievable recoveries in the presence of antiscalants for the RO unit, which were determined by the projection programs of seven different antiscalant suppliers. As can be seen, the recommended maximum achievable RO recovery was different for all the projection programs of the antiscalant suppliers. In addition, the scalant compound, which may limit RO recovery, was not the same, according to the projection programs of different suppliers. For instance, according to the projection programs of suppliers A, E, C, and G, recovery of the RO unit was limited due to calcium carbonate scaling, while calcium phosphate scaling was limiting $\mathrm{RO}$ recovery according to suppliers B, D, and F. The maximum achievable $\mathrm{RO}$ recovery (limited due to calcium carbonate) was $89 \%$ according to suppliers $\mathrm{E}$ and $\mathrm{G}$, and $83 \%$ and $87 \%$ according to suppliers $A$ and $C$, respectively. The maximum achievable $\mathrm{RO}$ recovery (limited due to calcium phosphate) was $77 \%, 80 \%$, and $85 \%$ according to suppliers $\mathrm{B}, \mathrm{D}$, and $\mathrm{F}$, respectively. From Figure $2 \mathrm{a}$, one can clearly recognise that the projection programs of the antiscalant suppliers are not consistent in identifying the maximum $\mathrm{RO}$ recovery. 

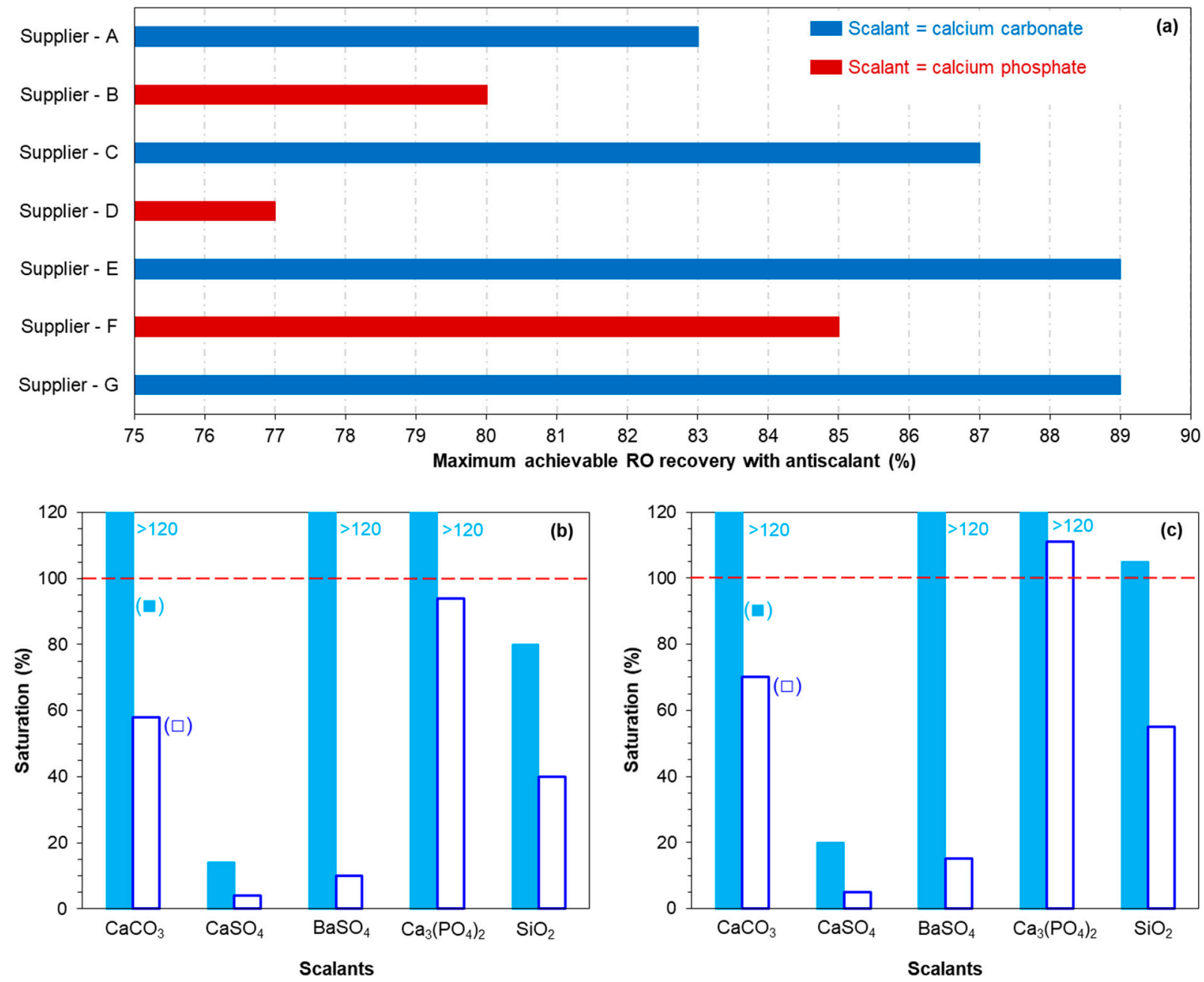

Figure 3. (a) Maximum achievable recovery of the RO unit in the presence of antiscalants determined with the projection programs of various antiscalant suppliers. (b) Scaling potential of commonly encountered scalants at $80 \%$ recovery of the RO unit ( $\square$ ) in the absence of antiscalant, and ( $\square$ ) in the presence of antiscalant. (c) Scaling potential of commonly encountered scalants at $85 \%$ recovery of the RO unit ( $\square)$ in the absence of antiscalant, and $(\square)$ in the presence of antiscalant. $(\mathbf{b}, \mathbf{c})$ are determined with the projection program of supplier B.

Figure $3 b, c$ present the scaling tendency (performed with the projection program of supplier B) of some commonly encountered scalants in the RO concentrate at 80 and $85 \%$ recovery, respectively. The scaling tendency of the RO concentrates at 80 and $85 \%$ recoveries is presented because the RO pilot, in this study, was operated initially at $80 \%$ recovery and then at $85 \%$ recovery. The scaling tendency is shown both with and without the addition of antiscalant to the RO feed.

The projection program of supplier B advised that at $80 \%$ recovery without antiscalant, the $\mathrm{RO}$ unit may experience calcium carbonate, barium sulphate, and calcium phosphate scaling, while with the addition of antiscalant to the RO feed, none of the mentioned scalants will precipitate in the RO unit. Furthermore, at $85 \%$ recovery with no antiscalant, the program indicated that silica may also precipitate together with calcium carbonate, barium sulphate, and calcium phosphate. The program suggested that, with the addition of antiscalant, calcium carbonate, barium sulphate, and silica may not precipitate in the RO unit at $85 \%$ recovery, while calcium phosphate may precipitate even with the addition of antiscalant. 
In short, with the use of projection programs, it is not clear if the $\mathrm{RO}$ unit in Kamerik can be operated at $85 \%$ recovery (or higher), as the highest achievable recovery according to antiscalant suppliers varied from 77 to $89 \%$.

\subsection{Foulant (Scalant) Characterization}

In this section, the aim was to understand which compounds may limit RO recovery. For this, the RO unit was initially operated at various recoveries without antiscalant, and in the case of a decrease in permeability, the membranes were taken out for autopsy to identify the scalants responsible for the observed permeability decline in the absence of antiscalants. After identifying the scalant(s), the $\mathrm{RO}$ was operated with various antiscalants of different suppliers in an attempt to inhibit the precipitation of those scalants and to maximize RO recovery (presented later in Section 3.3).

\subsubsection{RO Operation at $80-85 \%$ Recoveries in the Absence of Antiscalants}

Figure 4 presents the average normalized permeability of the first, second, and third stages of the RO unit at $80-85 \%$ recoveries when no antiscalant was added to the $\mathrm{RO}$ feed.
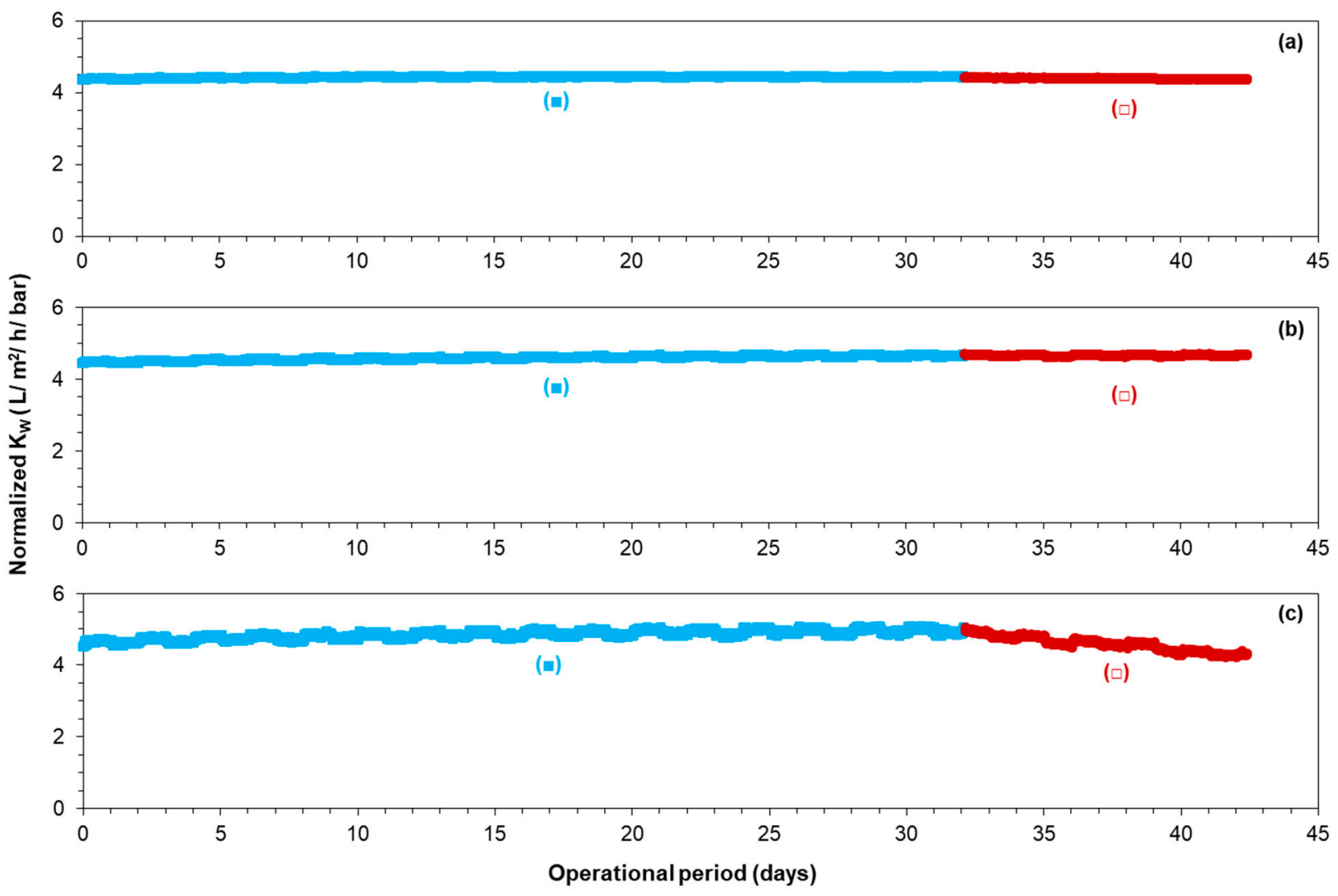

$\begin{array}{ll}\text { (घ) }) \text { Recovery }=80 \% & \text { ( } \square \text { ) Recovery }=85 \%\end{array}$

Figure 4. Average normalized permeability of the (a) first stage, (b) second stage, and (c) third stage of the RO unit at 80 and $85 \%$ recoveries without antiscalant addition.

At $80 \%$ recovery without antiscalant, the normalized permeability remained constant, where calcium carbonate, barium sulphate, and calcium phosphate had the tendency to scale the $\mathrm{RO}$ unit, according to the projection program of supplier B. On the other hand, at $85 \%$ recovery, the normalized permeability of the last stage decreased in the absence of antiscalants. At $85 \%$ recovery, the normalized permeability of the second stage remained constant, where the total recovery of the first and second stages was approximately $77 \%$. As no decrease in membrane permeability of the last stage at $80 \%$ recovery without antiscalant was observed, it was expected that permeability would remain constant at $77 \%$ recovery. 
Surprisingly, the average normalized permeability of the first stage with a recovery of $52 \%$ had a slight decreasing trend (with a-0.005 slope). The slight decrease in the first stage may not be due to the deposition/precipitation of newly formed particles/crystals. It could be that the $\mathrm{RO}$ feed contained particles that were deposited in the first stage and caused permeability decline. To understand what compounds caused permeability decline in the third stage and in the first stage, the tail elements of the mentioned stages were taken out for autopsy.

\subsubsection{Membrane Autopsy}

\section{SEM-EDX of the Tail Element of the First Stage}

The SEM and EDX analyses of the tail element of the first stage (with decreased permeability) are presented in Figure $5 a, b$, respectively. The SEM picture showed that the membrane surface was covered by deposits. The EDX results in Figure $5 \mathrm{~b}$ indicated that the deposited material on the membrane surface consisted of aluminium, silicon, and iron. In the EDX analysis (Figure 5b), only those elements that are not part of the membrane material are presented. The presence of aluminium and silicon on the membrane surface could be attributed to clay particles that might be present in the RO feedwater that were not retained by the $10 \mu \mathrm{m}$ cartridge filter. The presence of iron may be related to the deposited clay particles, as iron may be present in the composition of the clay particles, and/or to the iron oxide particles that may be present in very low concentrations in the RO feed.
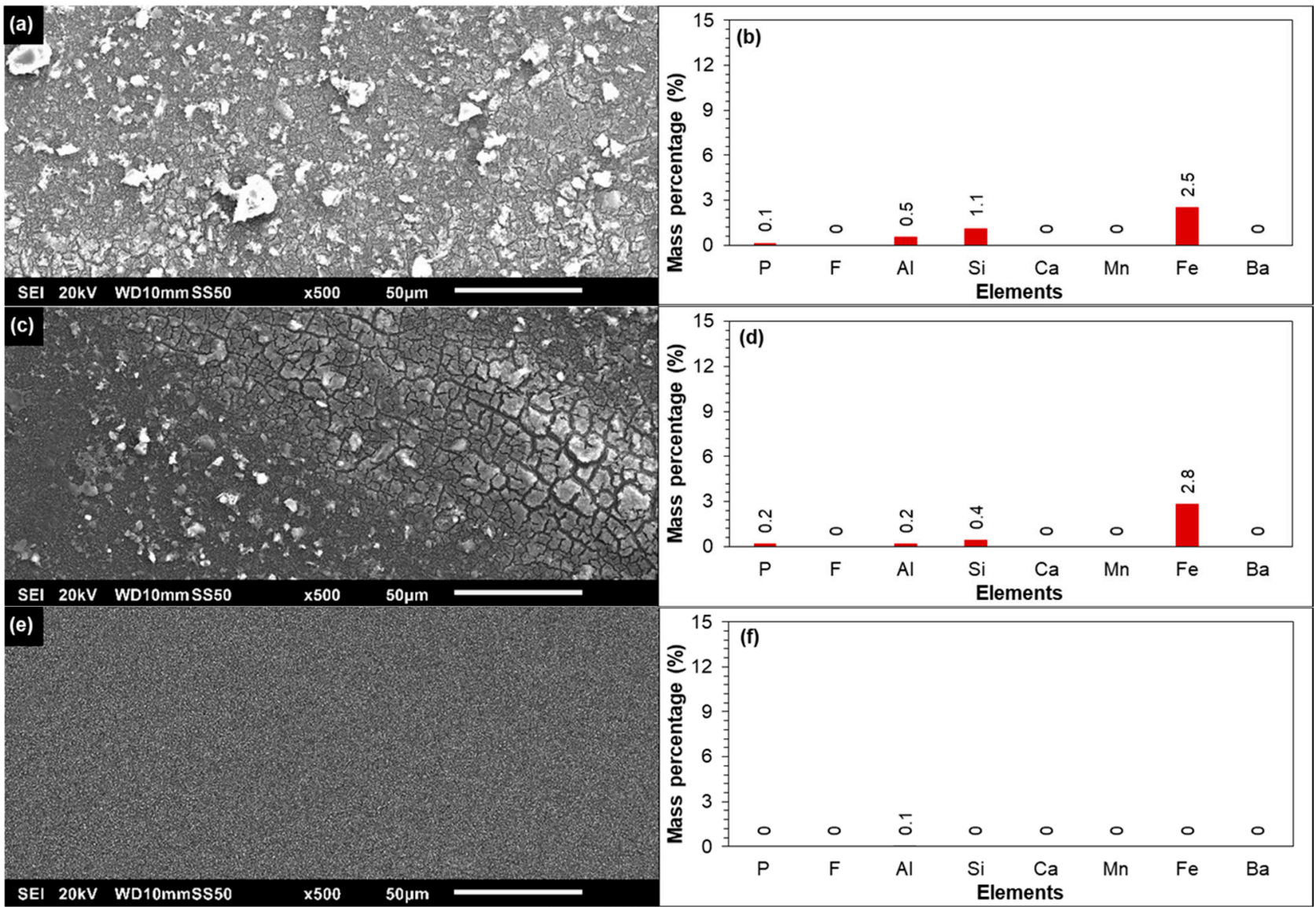

Figure 5. (a) SEM and (b) EDX analyses of the tail element of the first stage with decreased permeability. (c) SEM and (d) EDX analyses of the tail element of the first stage cleaned with a $0.05 \mathrm{M} \mathrm{NaOH}$ solution. (e) SEM and (f) EDX analyses of the tail element of the first stage cleaned with a $0.05 \mathrm{M}$ $\mathrm{HCl}$ solution. 
Figure 5c,d present the SEM image and the EDX of the membrane cleaned with $0.05 \mathrm{M}$ $\mathrm{NaOH}$ solution, respectively. It was observed that the $\mathrm{NaOH}$ solution was unable to remove the deposited particles from the membrane surface, and the layer (after cleaning) still consisted of aluminium, silicon, and iron. On the other hand, the deposited particles disappeared when the membrane was stirred in $0.05 \mathrm{M} \mathrm{HCl}$ solution (Figure $5 \mathrm{e}$ ). In the EDX analysis (Figure 5f), no aluminium, silicon, and iron were detected. This showed that the deposited layer was removed with $\mathrm{HCl}$ solution. At this point, it was not clear if the deposited particles were dissolved in the $\mathrm{HCl}$ solution and/or were detached from the membrane surface due to mechanical forces.

In Figure 6, the SEM-EDX analysis of the retained deposits on the $0.45 \mu \mathrm{m}$ filter (after filtering the $0.05 \mathrm{M} \mathrm{HCl}$ cleaning solution) is shown. As can be seen, the retained deposits consisted of aluminium, silicon, and iron suggesting that clay particles from the membrane surface were not dissolved in the $\mathrm{HCl}$ solution, but actually were detached from the membrane surface. Figure $6 \mathrm{~b}$ also indicated that a part of the iron on the membrane surface of the tail element of the first stage (Figure $5 a, b$ ) could be linked to clay particles, since if all iron was present as iron oxides, then it should have been dissolved in $0.05 \mathrm{M} \mathrm{HCl}$ solution. In Figure 6b, the mass percentage of iron (on the filter surface) was approximately half the mass percentage of silicon. However, in Figure 5b, the mass percentage of iron on the membrane surface of the tail element of the first stage was higher than silicon. This may indicate that the additional mass percentage of iron in Figure $5 \mathrm{~b}$ could be due to the iron oxide particles.
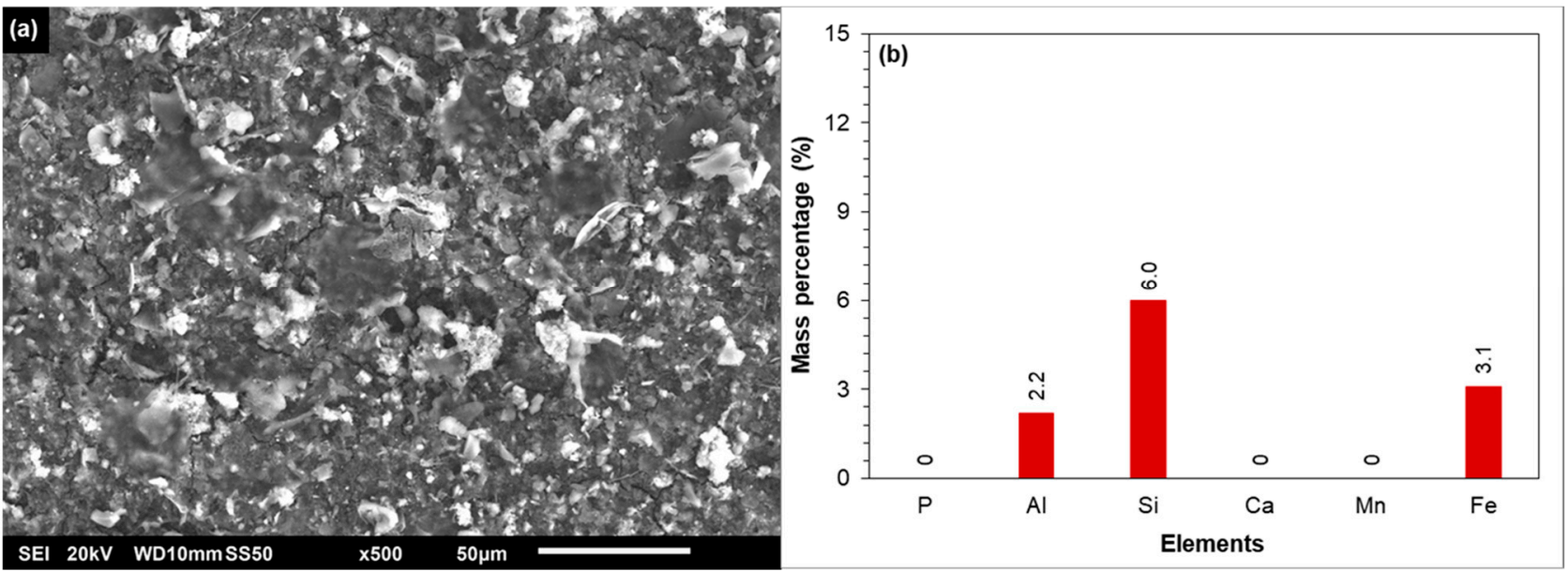

Figure 6. (a) SEM image and (b) EDX analysis of the $0.45 \mu \mathrm{m}$ filter after filtration of the $0.05 \mathrm{M} \mathrm{HCl}$ solution (of the tail element of the first stage).

In brief, based on the SEM-EDX results of Figures 5 and 6, it may be concluded that the deposition of clay and iron oxide particles (present in the RO feed) were contributing to the slight permeability decline of the first stage.

\section{SEM-EDX of the Tail Element of the Third Stage}

In Figure 7a,b, SEM-EDX analysis of the fouled/scaled RO membrane of the tail element of the third stage is shown. As can be seen, the membrane surface apparently was covered with an amorphous layer. According to the EDX analysis, the foulant was composed of calcium, phosphorous, and iron. A small mass percentage of manganese could also be observed. In the EDX analysis, aluminium and silicon were not observed on the membrane surface, which suggested that clay particles did not contribute to the permeability decline of the third stage at $85 \%$ recovery. According to the antiscalant projection program of supplier B (Figure 3c), calcium carbonate, barium sulphate, calcium phosphate, and silica have the potential to scale the $\mathrm{RO}$ at $85 \%$ recovery in the absence of antiscalant. As silica was not observed on the membrane surface in the EDX analysis 
(Figure $7 \mathrm{~b}$ ), it can be concluded that silica scaling did not occur in the $\mathrm{RO}$ unit at $85 \%$ recovery without antiscalant.

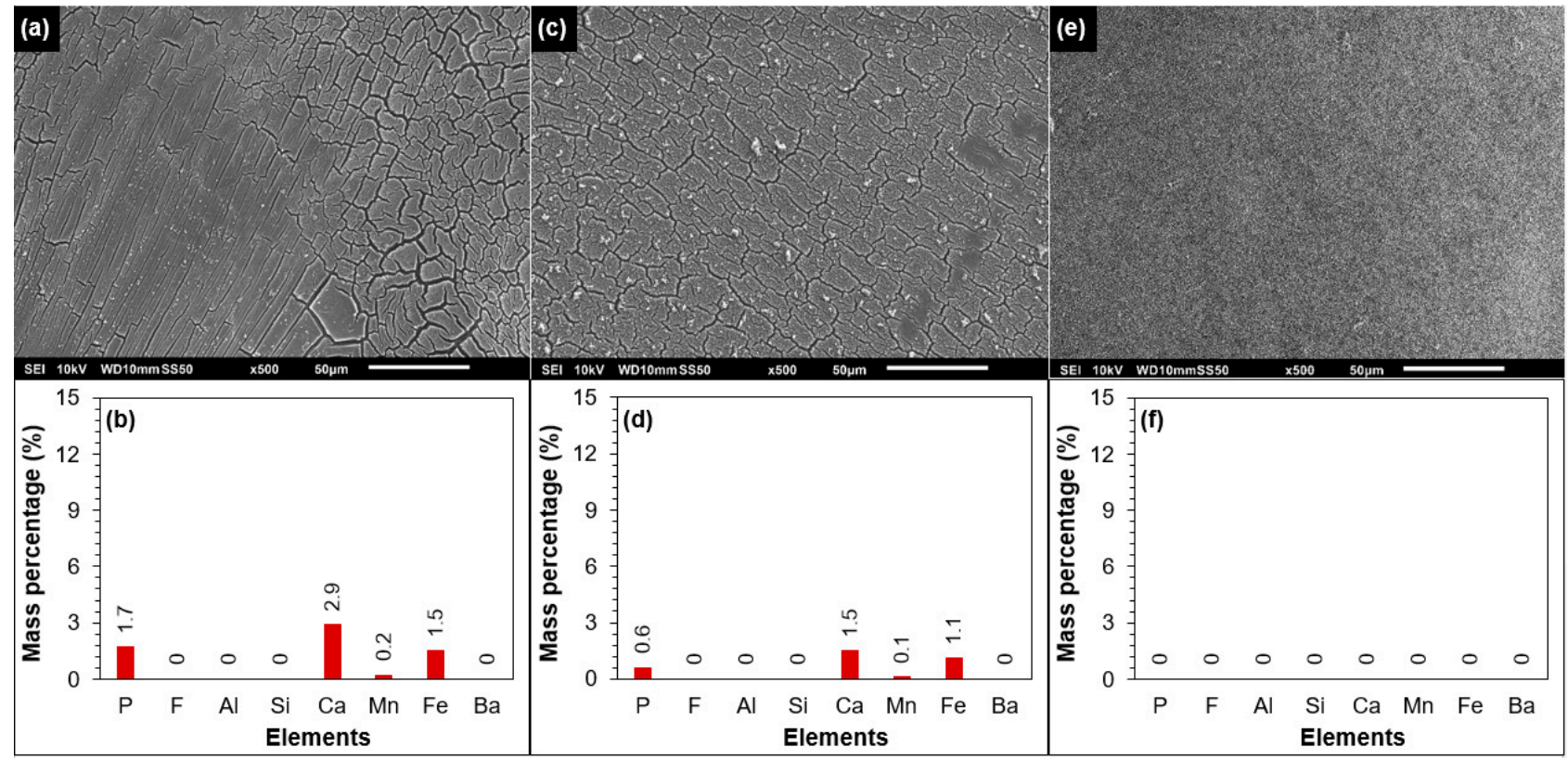

Figure 7. (a) SEM and (b) EDX analyses of the fouled tail element of the third stage. (c) SEM and (d) EDX analyses of the tail element of the third stage cleaned with $0.05 \mathrm{M} \mathrm{NaOH}$ solution. (e) SEM and (f) EDX analyses of the tail element of the third stage cleaned with $0.05 \mathrm{M} \mathrm{HCl}$ solution.

Furthermore, barium sulphate scaling did not occur at $85 \%$ recovery, as barium was not present on the fouled membrane surface (Figure 7b). Based on a study by Boerlage, et al. [37] where they reported that barium sulphate has very slow precipitation kinetics and its precipitation is hindered by humic substances (HS), it was expected that the barium sulphate scale would not occur in the RO unit in Kamerik. In the anaerobic groundwater of Kamerik (RO feed), the concentration of HS was approximately $5.3 \mathrm{mg} / \mathrm{L}$ (Table 1), which might inhibit barium sulphate scaling in the RO unit. Several researchers [38-42] have reported that HS significantly hinder the formation of calcium carbonate. Also, in a study by the current authors [36], it was demonstrated that HS, as well as the phosphate present in the GW, were able to inhibit calcium carbonate scaling in the RO unit in Kamerik. We showed that due to the presence of HS and phosphate, the induction time of the real RO concentrate at $80 \%$ recovery was longer than 7 days, whereas at the same supersaturation level in the absence of phosphate and HS, the induction time of the synthetic RO concentrate of $80 \%$ recovery was around $1 \mathrm{~h}$. Due to the long induction time $(>168 \mathrm{~h})$ of the $\mathrm{RO}$ concentrate of $85 \%$ recovery in the absence of antiscalants (Figure S1), it is also expected that calcium carbonate scaling would not occur at $85 \%$ recovery when antiscalants are not added to the RO feed. In the XRD analysis (Figure S2), calcium carbonate crystals were not detected, which also indicates that calcium carbonate scaling was not the reason for the permeability decline in the last stage, as seen in Figure 4c.

In Figure $7 \mathrm{~b}$, the mass percentage of calcium and phosphorous on the membrane surface could be attributed to (amorphous) calcium phosphate scaling, which was also predicted by the projection programs of suppliers B, D, and F (Figure 3a). However, the presence of iron on the fouled membrane is not clear. As aluminium and silicon were not observed on the fouled membrane of the third stage (Figure 7a), the presence of iron could not be due to clay particles. One may suggest that the presence of iron on the membrane could be due to the presence of iron oxide particles in the RO feed. The presence of iron (and also of calcium and phosphorous) on the fouled membrane is elucidated via XPS analysis later. 
Figure 7c,d presents the SEM-EDX analysis of the fouled membrane which was cleaned with $0.05 \mathrm{M} \mathrm{NaOH}$ solution. As can be seen, the alkaline solution (0.05 M NaOH) was unable to remove the foulant from the membrane surface. After cleaning at high $\mathrm{pH}$, calcium, phosphorous, and iron were still present on the membrane surface. On the other hand, the acidic solution $(0.05 \mathrm{M} \mathrm{HCl})$ was able to remove the foulant from the membrane surface, as can be seen from the SEM image (Figure 7e) and the EDX analysis (Figure 7f). As calcium, phosphorous, and iron were not detected on the membrane surface (Figure 7e), the acidic solution was filtered through a $0.45 \mu \mathrm{m}$ filter and then the filter was examined by SEM-EDX. It was found that the foulant (composed of calcium, phosphorous, and iron) on the tail element of the third stage was dissolved in the acidic solution (Figure S3).

In brief, from Figure 7, one can conclude that the foulant (on the membrane surface of the tail element of the third stage) was mainly inorganic, which could be dissolved in an acidic solution $(0.05 \mathrm{M} \mathrm{HCl})$, but not in an alkaline solution $(0.05 \mathrm{M} \mathrm{NaOH})$.

\section{XPS Analysis of the Tail Element of the Third Stage}

The fouled membrane (tail element of the third stage) was analysed with XPS analysis in an attempt to identify the scalant(s) to which calcium, phosphorous, and iron could be attributed. The survey spectrum of the analysis is shown in Figure S4. Calcium, phosphorous, iron, manganese, oxygen, nitrogen, sulphur, and carbon were all detected. In Table 5, the average atomic concentrations (obtained with the XPS analysis) from four different spots of the fouled membranes are shown. As the foulant layer was thin, nitrogen, sulphur, carbon, and partly oxygen could be attributed to the polyamide membrane. In the survey spectrum, aluminium and silicon were not observed, which further verified the results of SEM-EDX of Figure 7a,b, showing that clay particles were not (mainly) present on the membrane surface.

Table 5. Atomic concentrations of various elements (obtained via XPS analysis) of the fouled membrane.

\begin{tabular}{ccccccccc}
\hline Elements & $\mathbf{C}$ & $\mathbf{N}$ & $\mathbf{O}$ & $\mathbf{P}$ & $\mathbf{S}$ & $\mathbf{C a}$ & $\mathbf{M n}$ & $\mathbf{F e}$ \\
\hline $\begin{array}{c}\text { Average atomic } \\
\text { concentration }(\%)\end{array}$ & 46.35 & 1.9 & 38.47 & 3.45 & 1.18 & 6.19 & 0.47 & 1.98 \\
\hline Standard deviations & 0.9 & 0.29 & 0.48 & 0.42 & 0.06 & 0.32 & 0.17 & 0.26 \\
\hline
\end{tabular}

In Table 6, the binding energies of calcium, phosphorous, iron, and manganese (present on the fouled membrane surface) are given. In addition, for the determined binding energies, the identified compounds based on the XPS database of the National Institute of Standards and Technology (NIST) [43] are included in Table 6. The binding energies of calcium and phosphorous were $347.2 \mathrm{eV}$ and $132.9 \mathrm{eV}$, respectively, which corresponded to calcium phosphate compounds in the NIST database. This suggested that the presence of calcium and phosphorous on the fouled membrane surface (tail element of the third stage) can be attributed to calcium phosphate scaling, as predicted by the projection programs of suppliers B, D, and F (Figure 3a).

In the XPS analysis, the binding energies of iron and manganese were found to be $711.1 \mathrm{eV}$ and $624.4 \mathrm{eV}$, respectively. According to the NIST database, the presence of iron and manganese on the fouled membrane of the tail element of the third stage could be due to the precipitation of oxidized iron and manganese. This may suggest that iron oxide particles were present in the raw water ( $\mathrm{RO}$ feed) before entering the plant. It may also be that iron oxide particles were formed (and precipitated on the membrane surface) when the anaerobic $\mathrm{RO}$ concentrate (containing a ferrous concentration of approximately $57 \mathrm{mg} / \mathrm{L}$ ) came into contact with the aerobic RO permeate during flushing of the last stage, which was needed for membrane autopsy. If iron oxide particles were formed during flushing, then they were not responsible for the observed permeability decline of the last stage in Figure $4 \mathrm{c}$. 
Table 6. The binding energies of various elements on the fouled membrane (determined via XPS analysis).

\begin{tabular}{|c|c|c|}
\hline Element & Binding Energy (eV) & $\begin{array}{l}\text { Identified Compound(s) According to } \\
\text { the NIST Database }\end{array}$ \\
\hline Carbon (C1s) & 284.8 & Reference value \\
\hline Calcium $\left(\mathrm{Ca} 2 \mathrm{p}_{3 / 2}\right)$ & 347.2 & $\begin{array}{c}\mathrm{Ca}_{3}\left(\mathrm{PO}_{4}\right)_{2,} \mathrm{Ca}_{8} \mathrm{H}_{2}\left(\mathrm{PO}_{4}\right)_{6} \cdot 5 \mathrm{H}_{2} \mathrm{O} \\
\mathrm{Ca}_{10}\left(\mathrm{PO}_{4}\right)_{6}(\mathrm{OH})_{2}\end{array}$ \\
\hline Phosphorous $\left(\mathrm{P} 2 \mathrm{p}_{3 / 2}\right)$ & 132.9 & $\mathrm{Ca}_{3}\left(\mathrm{PO}_{4}\right)_{2}$ \\
\hline Iron $\left(\mathrm{Fe} 2 \mathrm{p}_{3 / 2}\right)$ & 711.1 & $\mathrm{Fe}_{2} \mathrm{O}_{3}$ \\
\hline Manganese $\left(\mathrm{Mn}^{2} \mathrm{p}_{3 / 2}\right)$ & 642.4 & $\mathrm{MnO}_{2}$ \\
\hline
\end{tabular}

Nevertheless, from the SEM-EDX analysis (Figure 7a,b) and XPS analysis (Tables 5 and 6), it can be concluded that calcium phosphate scaling was one of the reasons for the permeability decline of the third stage at $85 \%$ recovery (Figure $4 \mathrm{c}$ ) when no antiscalant was added to the RO feed.

\section{FEEM Analysis of the $0.05 \mathrm{M} \mathrm{HCl}$ and $0.05 \mathrm{M} \mathrm{NaOH}$ Cleaning Solutions}

As discussed earlier in Section 2.1 (Table 1), the dissolved organic carbon (DOC) concentration in the RO feed was approximately $8.6 \mathrm{mg} / \mathrm{L}$, of which $5.3 \mathrm{mg} / \mathrm{L}$ were HS. This means that the concentration of HS in the RO concentrate at $85 \%$ recovery could increase to approximately $35 \mathrm{mg} / \mathrm{L}$. In RO processes, HS are recognized by various researchers [44-47] to cause membrane fouling. Therefore, it was essential to investigate if HS also contributed to the permeability decline of the third stage (Figure 4c).

In Figure 8, fluorescence excitation-emission matrix (FEEM) analysis of the RO concentrate (at $85 \%$ recovery) and the $\mathrm{HCl}$ and $\mathrm{NaOH}$ cleaning solutions of the tail elements of the third stage are shown. In this study, the locations of the EEM peaks of humic acid (HA) and fulvic acid (FA) were based on the EEM regions reported by Chen et al. [48]. The HA peaks were observed in the 380-500 and $250-400 \mathrm{~nm}$ emission and excitation wavelength ranges, respectively, while the 380-400 and 200-250 nm emission and excitation wavelength ranges, respectively, were attributed to FA [48].
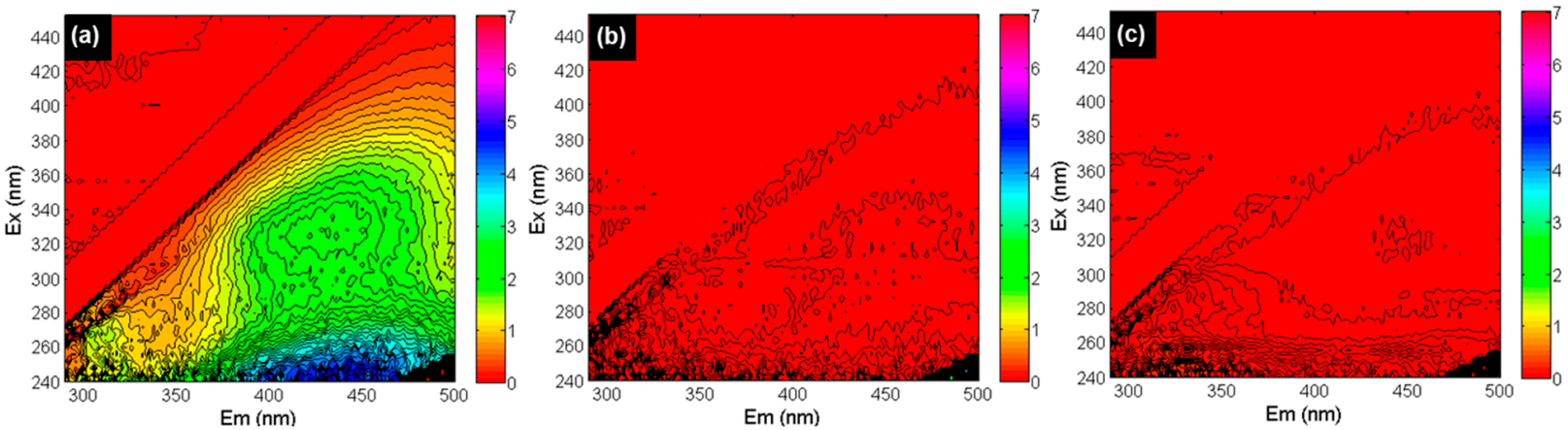

Figure 8. FEEM analysis of the (a) RO concentrate at $85 \%$ recovery, (b) $0.05 \mathrm{M} \mathrm{NaOH}$ cleaning solution, and (c) $0.05 \mathrm{M} \mathrm{HCl}$ cleaning solution (Ex and Em represent excitation and emission wavelengths).

As illustrated in Figure 8a, peaks for both HA and FA (with high intensity) were observed in the $\mathrm{RO}$ concentrate, which verifies the presence of HS in the anaerobic GW. However, HA and FA peaks were not visible in the cleaning solutions of the tail element of the third stage, as shown in Figure $8 \mathrm{~b}$ ( $\mathrm{NaOH}$ solution) and Figure $8 \mathrm{c}(\mathrm{HCl}$ solution). The absence of $\mathrm{HA}$ and FA peaks in the $\mathrm{HCl}$ and $\mathrm{NaOH}$ solutions suggests that $\mathrm{HS}$ were likely not responsible for the permeability decline of the third stage of the RO unit in Figure 4c. 


\subsection{Role of Antiscalants in Increasing RO Recovery to $85 \%$}

In the previous section, it was found that calcium phosphate was one of the scalants leading to the permeability decline of the $\mathrm{RO}$ unit at $85 \%$ recovery and was limiting the $\mathrm{RO}$ recovery when no antiscalant was added to the $\mathrm{RO}$ feed. The section aimed to investigate if the permeability decline at $85 \%$ could be prevented with the addition of antiscalants.

\subsubsection{RO Pilot Operation at $85 \%$ Recovery with Various Antiscalants}

In this section, five different antiscalants (Table 2) were tested that were claimed by the antiscalant suppliers to have excellent performance in preventing calcium phosphate scaling at $85 \%$ recovery. The aim was to increase the RO recovery to $85 \%$ (and even higher) with the use of antiscalants. Therefore, the RO pilot was operated at $85 \%$ recovery (Table 3 ) with the suppliers' recommended antiscalants and antiscalant doses.

Figure 9 shows the average normalized permeability of the third stage of the RO unit at $85 \%$ recovery in the absence and presence of the five tested antiscalants. As can be seen, none of the antiscalants could prevent the permeability decline of the third stage. After operating the $\mathrm{RO}$ unit with antiscalant (AS-5), the tail element of the third stage was examined with SEM-EDX, and the results were similar to those shown in Figure 7. It is worth mentioning that the permeability of the third stage also decreased at $83 \%$ recovery in the presence of antiscalants (Figure S5). The RO operation at 81 and $82 \%$ recovery was not investigated.
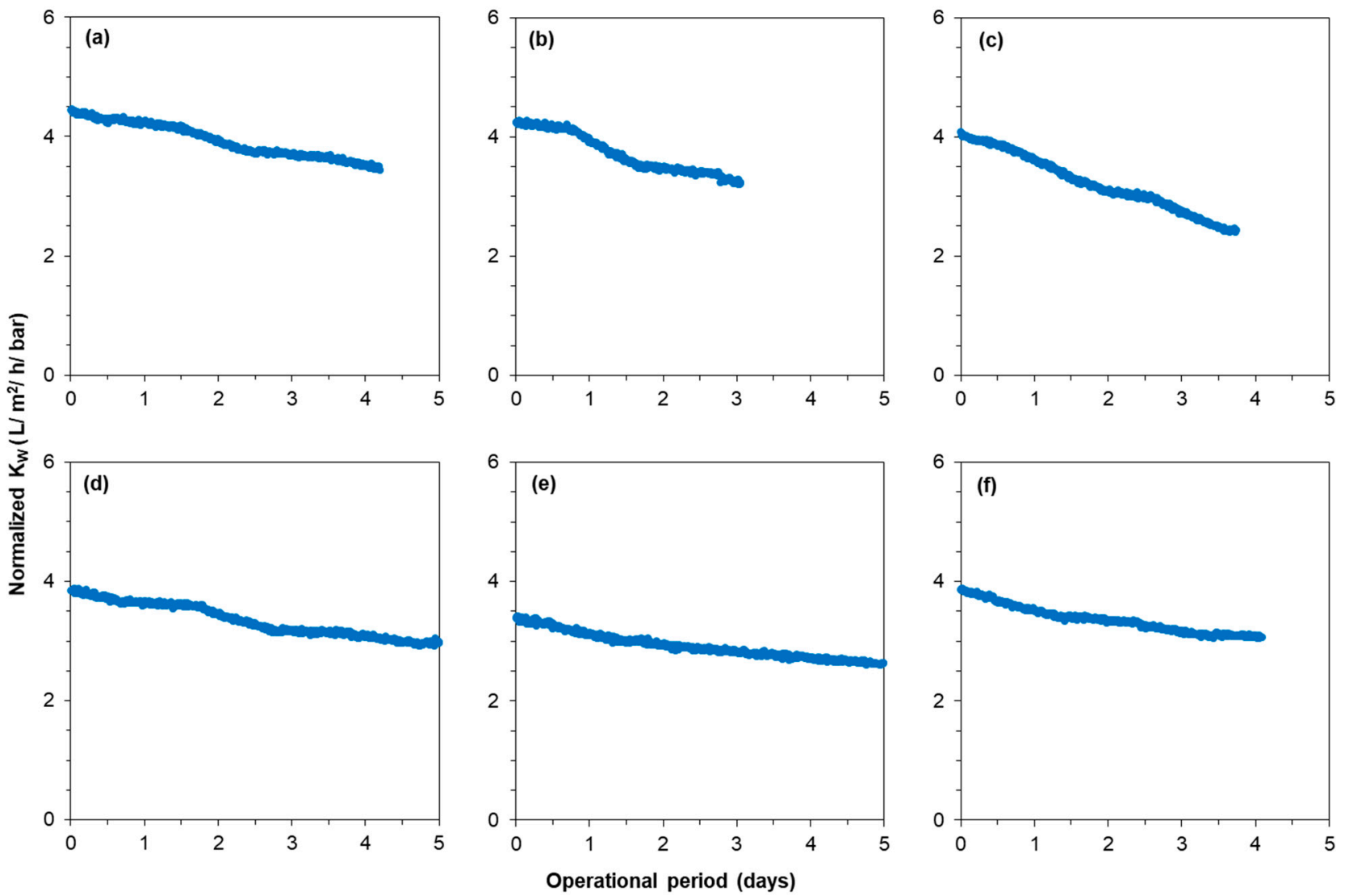

Figure 9. Average normalized permeability of the last stage of the $\mathrm{RO}$ unit at $85 \%$ recovery (a) without antiscalant, (b) with $2.5 \mathrm{mg} / \mathrm{L} \mathrm{AS}-1$, (c) with $2.5 \mathrm{mg} / \mathrm{L}$ AS-2, (d) with $2.5 \mathrm{mg} / \mathrm{L} \mathrm{AS}-3$, (e) with $5 \mathrm{mg} / \mathrm{L}$ AS-4, and (f) with $5 \mathrm{mg} / \mathrm{L}$ AS-5.

Some antiscalant suppliers claim that the effectiveness of their antiscalants is reduced when iron (II) is present in the RO feed. Furthermore, as the RO feed contained clay particles and probably iron oxide particles as well, it may be too early to conclude (based on 
the results of Figure 9) that antiscalants were not effective in preventing calcium phosphate scaling. It is worth mentioning that the tested antiscalants were claimed by the suppliers to have good performance in dispersing clay and iron oxide particles and not allowing them to deposit on the membrane.

Nevertheless, to understand if the tested antiscalants can prevent calcium phosphate scaling in the absence of iron (II), once-through lab-scale RO tests (Section 3.3.2) were performed with the synthetic concentrates of $85 \%$ recovery, where calcium phosphate was the only scalant that could cause permeability decline of the RO.

\subsubsection{Lab-Scale RO Tests with the Synthetic Concentrate of $85 \%$ Recovery with} Various Antiscalants

In the previous section (Section 3.3.1), due to the complexity of the water chemistry of the anaerobic GW, i.e., presence of iron and HS, it was not possible to conclude if antiscalants were effective in preventing calcium phosphate scaling at $85 \%$ recovery. The aim of this section was to see if antiscalants could prevent calcium phosphate scaling in once-through lab-scale RO tests using synthetic RO concentrates (Table 4) that had similar $\mathrm{pH}$, calcium, and phosphate concentrations to the real $\mathrm{RO}$ concentrates in Kamerik.

Figure 10a shows the normalized permeability of the TW30-1812-50 membrane element when fed with the synthetic concentrates of 80 and $85 \%$ recoveries in the absence of antiscalants (see Table 4 for the testing conditions). As can be seen, the normalized permeability of the membrane remained constant when fed with the synthetic concentrate of $80 \%$ recovery. This result is consistent with the $\mathrm{RO}$ pilot results (Figure $4 \mathrm{c}$ ), where the normalized permeability in the third stage remained constant at $80 \%$ recovery without antiscalant. On the other hand, when the membrane element was fed with the synthetic concentrate of $85 \%$ recovery, the normalized permeability decreased sharply, as illustrated in Figure 10a. This result also verifies that calcium phosphate was one of the scalants that caused permeability decline of the third stage of the RO pilot in Figure 4c. A SEM image and an EDX analysis of the membrane with decreased permeability (Figure 10a) are given in Figure 10c,d, respectively. As can be seen, the membrane surface was covered with an amorphous layer (verified with XRD analysis (Figure S6)) of calcium phosphate particles. In the EDX analysis, the mass percentage of fluoride, aluminium, silicon, manganese, iron, and barium was zero, which was because they were not present in the synthetic concentrate of $85 \%$ recovery.

Figure 10b shows the normalized permeability of the RO when fed with the synthetic concentrate of $85 \%$ recovery in the presence of $33 \mathrm{mg} / \mathrm{L}$ (equivalent to $5 \mathrm{mg} / \mathrm{L}$ dose in the RO feed) of various antiscalants. The normalized permeability decreased by at least $10 \%$ with each antiscalant in a $3 \mathrm{~h}$ experimental period, indicating that none of the antiscalants could prevent calcium phosphate scaling. From Figure 10b, one can also observe that the poor performance of the antiscalants in preventing the permeability decline of the third stage of the RO unit in Figure 9 was not (mainly) due to the presence of a high concentration of iron (II). The permeability of the small RO element in Figure 10b decreased more sharply than the permeability of the third stage of the RO unit in Figure 9. One possible explanation is that the supersaturation level of calcium phosphate in the synthetic RO concentrate was slightly higher than that of the real $\mathrm{RO}$ concentrate because the once-through lab-scale $\mathrm{RO}$ experiments were performed at room temperature (approximately $22{ }^{\circ} \mathrm{C}$ ), whereas the $\mathrm{RO}$ concentrate was at around $12{ }^{\circ} \mathrm{C}$. Furthermore, Figure 9 shows the average permeability of three membrane elements, implying that the actual permeability decline of the last element of the $\mathrm{RO}$ unit could be sharper than the ones of third stage shown in Figure 9.

To summarize, calcium phosphate appeared to be one of the primary scalants precipitating in the RO unit in Kamerik, and the available antiscalants for calcium phosphate were unable to prevent calcium phosphate scaling and increase $\mathrm{RO}$ recovery to $85 \%$. 

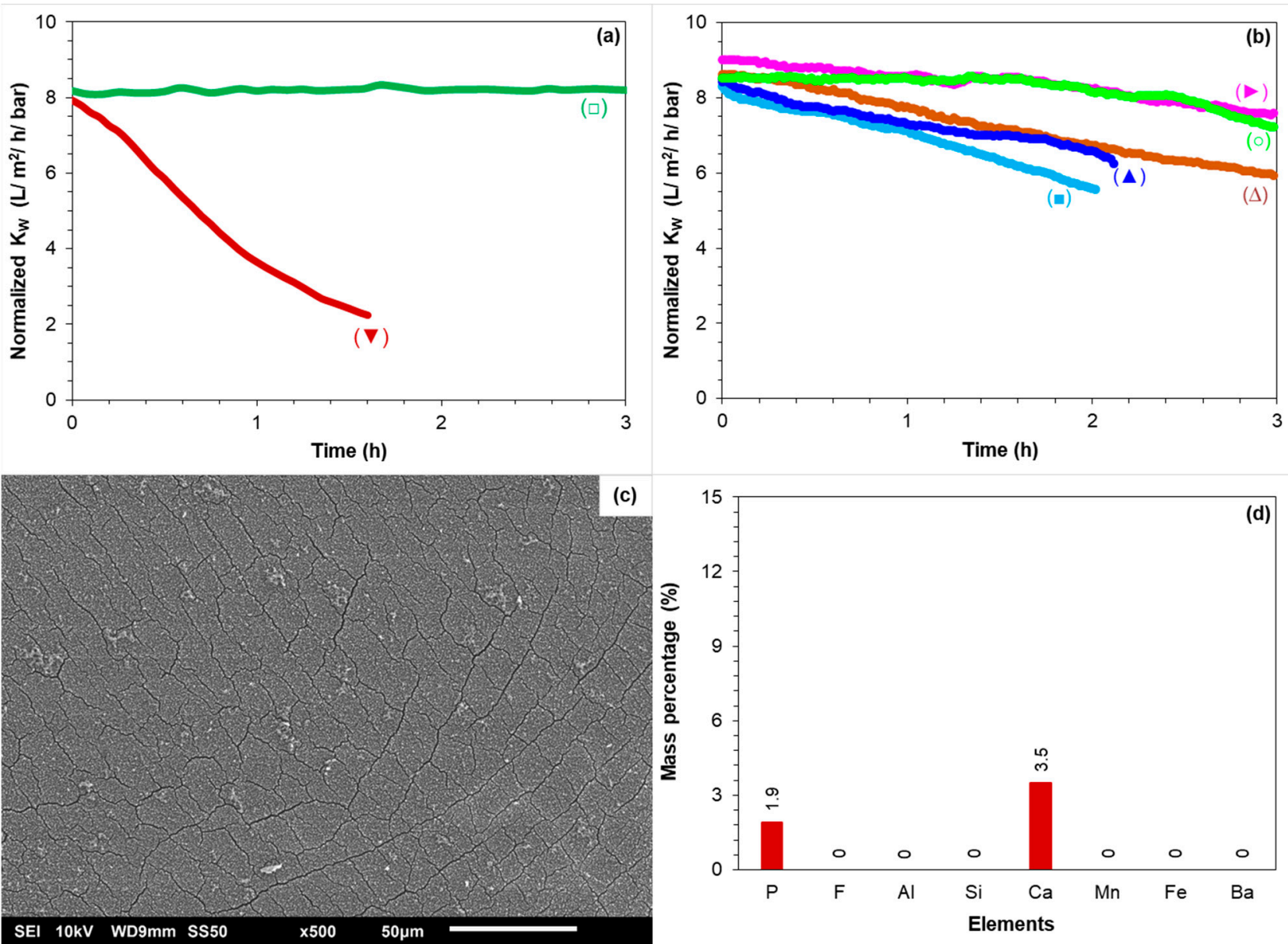

Figure 10. (a) Normalized $\mathrm{K}_{\mathrm{w}}$ of the small RO element when fed with the synthetic concentrates of $(\square) 80 \%$ recovery without antiscalant and $(\boldsymbol{\nabla})$ 85\% recovery without antiscalant. (b) Normalized $\mathrm{K}_{\mathrm{w}}$ of the small RO element when fed with the synthetic concentrates of $85 \%$ recovery with $33.3 \mathrm{mg} / \mathrm{L}$

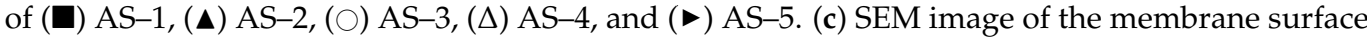
fouled with calcium phosphate without antiscalant addition. (d) EDX analysis of the membrane fouled with calcium phosphate without antiscalant addition.

\section{Conclusions}

In this study, the role of antiscalants in increasing the recovery of a future RO system of a Dutch water supply company, which will treat anaerobic groundwater in Kamerik (the Netherlands) for drinking water production, to at least $85 \%$ and the scalants that could limit RO recovery were investigated.

The following are the main findings of this study:

1. The maximum achievable recovery and the scalant limiting the $\mathrm{RO}$ recovery varied according to the projection programs of the different antiscalant suppliers, with some pointing to calcium carbonate and others to calcium phosphate as the limiting scaling compound. The maximum achievable recovery according to antiscalant suppliers was ranging between $77 \%$ and $89 \%$.

2. Operation of the $\mathrm{RO}$ at $80-85 \%$ recoveries without antiscalant:

a. The normalized permeability of the third stage remained constant during a 1 month experimental period when the $\mathrm{RO}$ pilot was operated at $80 \%$ recovery without antiscalant, whereas the normalized permeability of the third stage decreased when the RO pilot was operated at $85 \%$ recovery without antiscalant.

3. Membrane autopsy of the tail element of the third stage: 
a. Calcium phosphate was the main scalant causing permeability decline at $85 \%$ recovery and limiting the RO recovery.

b. Calcium carbonate was not responsible for the permeability decline of the third stage at $85 \%$ recovery.

4. Role of antiscalants in increasing the $\mathrm{RO}$ recovery to $85 \%$ (and higher):

a. In the RO pilot measurements, the tested antiscalants were found to be ineffective in increasing the $\mathrm{RO}$ recovery to $85 \%$ as the permeability of the third stage decreased with each of the tested antiscalants.

b. In once-through lab-scale RO tests, none of the tested antiscalants could prevent calcium phosphate scaling when the RO element was fed with the synthetic concentrate of $85 \%$ recovery.

Supplementary Materials: The following supporting information can be downloaded at: https: / / www.mdpi.com/article/10.3390/membranes12030290/s1, Figure S1: Induction time (IT) of the ( $(\mathbf{\Delta})$ real $\mathrm{RO}$ concentrate at $85 \%$ recovery without antiscalant, and ( $\square$ ) artificial RO concentrate of $85 \%$ recovery without antiscalant; Figure S2: XRD analysis of the fouled membrane (tail element) of the 3rd stage; Figure S3: (a) SEM image and (b) EDX analysis of the $0.45 \mu \mathrm{m}$ filter after filtration of the $0.05 \mathrm{M} \mathrm{HCl}$ solution (of the tail element of the 3rd stage); Figure S4: (a) XPS analysis of the fouled membrane (tail element) of the 3rd stage; Figure S5: (a) Average normalized permeability of the last stage of the RO unit at $83 \%$ recovery (a) without antiscalant, (b) with $2.0 \mathrm{mg} / \mathrm{L} \mathrm{AS}-1$, and (c) with $2.0 \mathrm{mg} / \mathrm{L}$ AS-2; Figure S6: XRD analysis of the small RO element fouled with calcium phosphate in once-through lab-scale RO measurements.

Author Contributions: Conceptualization, M.N.M., B.B., J.C.S., M.D.K., W.G.J.v.d.M.; methodology, M.N.M.; investigation, M.N.M.; writing—original draft preparation, M.N.M.; writing-review and editing, M.N.M., S.G.S.-R., J.D., B.B., V.A.Y.-Q., A.J.B.K., J.C.S., M.D.K., W.G.J.v.d.M.; visualization, M.N.M., B.B.; supervision, S.G.S.-R., J.D., B.B., V.A.Y.-Q., A.J.B.K., J.C.S., W.G.J.v.d.M., M.D.K.; project administration, S.G.S.-R., J.D., M.D.K., W.G.J.v.d.M. All authors have read and agreed to the published version of the manuscript.

Funding: This research received no external funding.

Institutional Review Board Statement: Not applicable.

Informed Consent Statement: Not applicable.

Data Availability Statement: Not applicable.

Acknowledgments: We thank Gerard Kip (Nanolab, University of Twente, The Netherlands) for his technical assistance with the XPS analysis of our samples.

Conflicts of Interest: The authors declare no conflict of interest.

\section{References}

1. Beyer, F.; Rietman, B.M.; Zwijnenburg, A.; van den Brink, P.; Vrouwenvelder, J.S.; Jarzembowska, M.; Laurinonyte, J.; Stams, A.J.M.; Plugge, C.M. Long-term performance and fouling analysis of full-scale direct nanofiltration (NF) installations treating anoxic groundwater. J. Membr. Sci. 2014, 468, 339-348. [CrossRef]

2. Hiemstra, P.; Kolpa, R.; Eekhout, J.M.J.M.; Kessel, T.; Adamse, E.; Paassen, J. 'Natural' recharge of groundwater: Bank infiltration in the Netherlands. J. Water Supply Res. Technol.-AQUA 2003, 52, 37-47. [CrossRef]

3. de Vet, W.; Genuchten, C.; van Loosdrecht, M.; Dijk, J. Water quality and treatment of river bank filtrate. Drink. Water Eng. Sci. Discuss. 2009, 3, 79-90. [CrossRef]

4. Kucera, J. Reverse Osmosis Membrane Fouling Control. In The Science and Technology of Industrial Water Treatment; CRC Press: Boca Raton, FL, USA, 2010. [CrossRef]

5. Tang, C.Y.; Chong, T.H.; Fane, A.G. Colloidal interactions and fouling of NF and RO membranes: A review. Adv. Coll. Interface Sci. 2011, 164, 126-143. [CrossRef] [PubMed]

6. Fridjonsson, E.O.; Vogt, S.J.; Vrouwenvelder, J.S.; Johns, M.L. Early non-destructive biofouling detection in spiral wound RO membranes using a mobile earth's field NMR. J. Membr. Sci. 2015, 489, 227-236. [CrossRef]

7. Okamoto, Y.; Lienhard, J.H. How RO membrane permeability and other performance factors affect process cost and energy use: A review. Desalination 2019, 470, 114064. [CrossRef]

8. Flemming, H.C. Mechanistic aspects of reverse osmosis membrane biofouling and prevention. Reverse Osm. 1993, 163-209. 
9. Potts, D.E.; Ahlert, R.C.; Wang, S.S. A critical review of fouling of reverse osmosis membranes. Desalination 1981, 36, 235-264. [CrossRef]

10. Pandey, S.R.; Jegatheesan, V.; Baskaran, K.; Shu, L. Fouling in reverse osmosis (RO) membrane in water recovery from secondary effluent: A review. Rev. Environ. Sci. Biol./Technol. 2012, 11, 125-145. [CrossRef]

11. Rodriguez, S.G.S. Particulate and Organic Matter Fouling of Seawater Reverse Osmosis Systems: Characterization, Modelling and Applications. UNESCO-IHE PhD Thesis; CRC Press/Balkema: Delft, The Netherlands, 2011.

12. Martínez, C.; Gómez, V.; Pocurull, E.; Borrull, F. Characterization of organic fouling in reverse osmosis membranes by headspace solid phase microextraction and gas chromatography-mass spectrometry. Water Sc. Technol. 2014, 71, 117-125. [CrossRef]

13. Xu, P.; Drewes, J.E.; Kim, T.-U.; Bellona, C.; Amy, G. Effect of membrane fouling on transport of organic contaminants in NF/RO membrane applications. J. Membr. Sci. 2006, 279, 165-175. [CrossRef]

14. Vrouwenvelder, J.S.; Graf von der Schulenburg, D.A.; Kruithof, J.C.; Johns, M.L.; van Loosdrecht, M.C.M. Biofouling of spiralwound nanofiltration and reverse osmosis membranes: A feed spacer problem. Water Res. 2009, 43, 583-594. [CrossRef]

15. Vrouwenvelder, H.S.; van Paassen, J.A.M.; Folmer, H.C.; Hofman, J.A.M.H.; Nederlof, M.M.; van der Kooij, D. Biofouling of membranes for drinking water production. Desalination 1998, 118, 157-166. [CrossRef]

16. Flemming, H.-C. Reverse osmosis membrane biofouling. Exp. Therm. Fluid Sci. 1997, 14, 382-391. [CrossRef]

17. Hiemstra, P.; Van Paassen, J.; Rietman, B.; Verdouw, J. Aerobic versus anaerobic nanofiltration: Fouling of membranes. In Proceedings of the AWWA Membrane Conference, Long Beach, CA, USA, 28 February-3 March 1999.

18. Ruiz-García, A.; Feo-García, J. Estimation of maximum water recovery in RO desalination for different feedwater inorganic compositions. Desalin. Water Treat. 2017, 70, 34-45. [CrossRef]

19. Ruiz-García, A.; Feo-García, J. Antiscalant cost and maximum water recovery in reverse osmosis for different inorganic composition of groundwater. Desalin. Water Treat. 2017, 73, 46-53. [CrossRef]

20. Antony, A.; Low, J.H.; Gray, S.; Childress, A.E.; Le-Clech, P.; Leslie, G. Scale formation and control in high pressure membrane water treatment systems: A review. J. Membr. Sci. 2011, 383, 1-16. [CrossRef]

21. Tzotzi, C.; Pahiadaki, T.; Yiantsios, S.G.; Karabelas, A.J.; Andritsos, N. A study of CaCO3 scale formation and inhibition in RO and NF membrane processes. J. Membr. Sci. 2007, 296, 171-184. [CrossRef]

22. Koutsoukos, P. Calcium carbonate scale control in industrial water systems. In The Science and Technology of Industrial Water Treatment; CRC Press: Boca Raton, FL, USA, 2010. [CrossRef]

23. Chesters, S.P. Innovations in the inhibition and cleaning of reverse osmosis membrane scaling and fouling. Desalination 2009, 238, 22-29. [CrossRef]

24. Greenberg, G.; Hasson, D.; Semiat, R. Limits of RO recovery imposed by calcium phosphate precipitation. Desalination 2005, 183, 273-288. [CrossRef]

25. Dorozhkin, S.V. Calcium orthophosphates (CaPO4): Occurrence and properties. Prog. Biomater. 2016, 5, 9-70. [CrossRef] [PubMed]

26. Mangal, M.N.; Salinas-Rodriguez, S.G.; Dusseldorp, J.; Kemperman, A.J.B.; Schippers, J.C.; Kennedy, M.D.; van der Meer, W.G.J. Effectiveness of antiscalants in preventing calcium phosphate scaling in reverse osmosis applications. J. Membr. Sci. 2021, 623, 119090. [CrossRef]

27. Neofotistou, E.; Demadis, K.D. Use of antiscalants for mitigation of silica $\left(\mathrm{SiO}_{2}\right)$ fouling and deposition: Fundamentals and applications in desalination systems. Desalination 2004, 167, 257-272. [CrossRef]

28. Luo, M.; Wang, Z. Complex fouling and cleaning-in-place of a reverse osmosis desalination system. Desalination 2001, 141, 15-22. [CrossRef]

29. Gallego, S.; Vigo, F.d.; Chesters, S.; Buñuel, P.L. Practical experience with high silica concentration in RO waters. In Proceedings of the WIM International Congress, Santiago, Chile, 9-11 July 2008.

30. Lee, S.; Kim, J.; Lee, C.-H. Analysis of CaSO4 scale formation mechanism in various nanofiltration modules. J. Membr. Sci. 1999, 163, 63-74. [CrossRef]

31. Pervov, A.G. Scale formation prognosis and cleaning procedure schedules in reverse osmosis systems operation. Desalination 1991, 83, 77-118. [CrossRef]

32. Greenlee, L.F.; Testa, F.; Lawler, D.F.; Freeman, B.D.; Moulin, P. The effect of antiscalant addition on calcium carbonate precipitation for a simplified synthetic brackish water reverse osmosis concentrate. Water Res. 2010, 44, 2957-2969. [CrossRef]

33. Chen, T.; Chen, P.; Montgomerie, H.; Hagen, T.; Leschied, C. Calcium Carbonate: Polymorph Stabilization in the Presence of Inhibitors. In The Science and Technology of Industrial Water Treatment; IWA Publishing: London, UK, 2009; pp. 61-79.

34. Drak, A.; Glucina, K.; Busch, M.; Hasson, D.; Laîne, J.-M.; Semiat, R. Laboratory technique for predicting the scaling propensity of RO feed waters. Desalination 2000, 132, 233-242. [CrossRef]

35. van Engelen, G.; Nolles, R. A sustainable antiscalant for RO processes. Desalin. Water Treat. 2013, 51, 921-923. [CrossRef]

36. Mangal, M.N.; Salinas-Rodriguez, S.G.; Blankert, B.; Yangali-Quintanilla, V.A.; Schippers, J.C.; van der Meer, W.G.J.; Kennedy, M.D. Role of phosphate and humic substances in controlling calcium carbonate scaling in a groundwater reverse osmosis system. J. Environ. Chem. Eng. 2021, 9, 105651. [CrossRef]

37. Boerlage, Ś.F.E.; Kennedy, M.D.; Bremere, I.; Witkamp, G.J.; van der Hoek, J.P.; Schippers, J.C. Stable barium sulphate supersaturation in reverse osmosis. J. Membr. Sci. 2000, 179, 53-68. [CrossRef] 
38. Hoch, A.R.; Reddy, M.M.; Aiken, G.R. Calcite crystal growth inhibition by humic substances with emphasis on hydrophobic acids from the Florida Everglades. Geochim. Et Cosmochim. Acta 2000, 64, 61-72. [CrossRef]

39. Zuddas, P.; Pachana, K.; Faivre, D. The influence of dissolved humic acids on the kinetics of calcite precipitation from seawater solutions. Chem. Geol. 2003, 201, 91-101. [CrossRef]

40. Klepetsanis, P.G.; Kladi, A.; Ostvold, T.; Kontoyiannis, C.G.; Koutsoukos, P.G.; Amjad, Z.; Reddy, M.M. The inhibition of calcium carbonate formation in aqueous supersaturated solutions, spontaneous precipitation and seeded crystal growth. In Advances in Crystal Growth Inhibition Technologies; Amjad, Z., Ed.; Springer: Boston, MA, USA, 2002; pp. 123-137.

41. Amjad, Z.; Pugh, J.; Reddy, M. Kinetic inhibition of calcium carbonate crystal growth in the presence of natural and synthetic organic inhibitors. In Water Soluble Polymers: Solution Properties and Application; Plenum Press: New York, NY, USA, 1998; pp. 131-147.

42. Inskeep, W.P.; Bloom, P.R. Kinetics of calcite precipitation in the presence of water-soluble organic ligands. Soil Sci. Soc. Am. J. 1986, 50, 1167-1172. [CrossRef]

43. NIST Standard Reference Database Number 20; NIST X-ray Photoelectron Spectroscopy Database. National Institute of Standards and Technology: Gaithersburg, MD, USA, 2000.

44. Tanaka, R.; Samu, Y.; Suzuki, T.; Niinae, M.; Lin, L.; Luh, J.; Coronell, O. The effects of humic acid fouling on the performane of polyamide composite reverse osmosis membranes. J. MMIJ 2016, 132, 123-128. [CrossRef]

45. Tang, C.; Kwon, Y.-N.; Leckie, J. Characterization of humic acid fouled reverse osmosis and nanofiltration membranes by transmission electron microscopy and streaming potential measurements. Environ. Sci. Technol. 2007, 41, 942-949. [CrossRef]

46. Tang, C.Y.; Kwon, Y.-N.; Leckie, J.O. Fouling of reverse osmosis and nanofiltration membranes by humic acid-effects of solution composition and hydrodynamic conditions. J. Membr. Sci. 2007, 290, 86-94. [CrossRef]

47. Zhao, X.; Wu, Y.; Zhang, X.; Tong, X.; Yu, T.; Wang, Y.; Ikuno, N.; Ishii, K.; Hu, H. Ozonation as an efficient pretreatment method to alleviate reverse osmosis membrane fouling caused by complexes of humic acid and calcium ion. Front. Environ. Sci. Eng. 2019, 13, 55. [CrossRef]

48. Chen, W.; Westerhoff, P.; Leenheer, J.A.; Booksh, K. Fluorescence excitation-emission matrix regional integration to quantify spectra for dissolved organic matter. Environ. Sci. Technol. 2003, 37, 5701-5710. [CrossRef] 